Old Dominion University

ODU Digital Commons

\title{
Influences of Hillslope Biogeochemistry on Anaerobic Soil Organic Matter Decomposition in a Tundra Watershed
}

\author{
Michael Philben \\ Neslihan Taş \\ Hongmei Chen \\ Old Dominion University, hxchen@odu.edu \\ Stan D. Wullschleger \\ Alexander Kholodov
}

See next page for additional authors

Follow this and additional works at: https://digitalcommons.odu.edu/chemistry_fac_pubs

Part of the Organic Chemistry Commons

\section{Original Publication Citation}

Philben, M., Taş, N., Chen, H., Wullschleger, S. D., Kholodov, A., Graham, D. E., \& Gu, B. (2020). Influences of hillslope biogeochemistry on anaerobic soil organic matter decomposition in a tundra watershed. Journal of Geophysical Research. Biogeosciences, 125(7), 1-14, Article e2019JG005512. https://doi.org/10.1029/ 2019JG005512

This Article is brought to you for free and open access by the Chemistry \& Biochemistry at ODU Digital Commons. It has been accepted for inclusion in Chemistry \& Biochemistry Faculty Publications by an authorized administrator of ODU Digital Commons. For more information, please contact digitalcommons@odu.edu. 
Authors

Michael Philben, Neslihan Taş, Hongmei Chen, Stan D. Wullschleger, Alexander Kholodov, David E. Graham, and Baohua Gu 


\section{JGR Biogeosciences}

\author{
RESEARCH ARTICLE \\ 10.1029/2019JG005512 \\ Key Points: \\ - We compared $\mathrm{CO}_{2}$ and $\mathrm{CH}_{4}$ \\ production in soils from two \\ wetland areas along a tundra \\ hillslope gradient (toeslope and peat \\ plateau) \\ - Production of both gasses was \\ higher in the organic toeslope soils, \\ while microbial $\mathrm{N}$ limitation was \\ higher in peat plateau soils \\ - Downslope transport of N, DOM, \\ and alkalinity increases greenhouse \\ gas production in the organic \\ toeslope soils
}

Supporting Information:

- Supporting Information S1

Correspondence to:

M. Philben and B. Gu,

philben@hope.edu;

gub1@ornl.gov

Citation:

Philben, M., Taş, N., Chen, H., Wullschleger, S. D., Kholodov, A., Graham, D. E., \& Gu, B. (2020). Influences of hillslope biogeochemistry on anaerobic soil organic matter decomposition in a tundra watershed. Journal of Geophysical Research: Biogeosciences, 125, e2019JG005512. https://doi.org/10.1029/2019JG005512

Received 8 OCT 2019 Accepted 24 APR 2020 Accepted article online 29 APR 2020

(C)2020. American Geophysical Union. All Rights Reserved. This article has been contributed to by U.S. Government employees and their work is in the public domain in the USA.

\section{Influences of Hillslope Biogeochemistry on Anaerobic Soil Organic Matter Decomposition in a Tundra Watershed}

\author{
Michael Philben $^{1,2}$ (D), Neslihan Taş ${ }^{3}$ D, Hongmei Chen ${ }^{4}$ (D), Stan D. Wullschleger ${ }^{1}$ (D), \\ Alexander Kholodov ${ }^{5}$, David E. Graham ${ }^{6}$ (D) and Baohua Gu$^{1}$ (D) \\ ${ }^{1}$ Environmental Sciences Division, Oak Ridge National Laboratory, Oak Ridge, TN, USA, ${ }^{2}$ Now at Department of Geology \\ and Environmental Science, Hope College, Holland, MI, USA, ${ }^{3}$ Climate and Ecosystem Sciences Division, Lawrence \\ Berkeley National Laboratory, Berkeley, CA, USA, ${ }^{4}$ Department of Chemistry and Biochemistry, Old Dominion \\ University, Norfolk, VA, USA, ${ }^{5}$ Geophysical Institute, University of Alaska Fairbanks, Fairbanks, AK, USA, ${ }^{6}$ Biosciences \\ Division, Oak Ridge National Laboratory, Oak Ridge, TN, USA
}

\begin{abstract}
We investigated rates and controls on greenhouse gas $\left(\mathrm{CO}_{2}\right.$ and $\left.\mathrm{CH}_{4}\right)$ production in two contrasting water-saturated tundra soils within a permafrost-affected watershed near Nome, Alaska, United States. Three years of field sample analysis have shown that soil from a fen-like area in the toeslope of the watershed had higher $\mathrm{pH}$ and higher porewater ion concentrations than soil collected from a bog-like peat plateau at the top of the hillslope. The influence of these contrasting geochemical and topographic environments on $\mathrm{CO}_{2}$ and $\mathrm{CH}_{4}$ production was tested in soil microcosms by incubating both the organic- and mineral-layer soils anaerobically for 55 days. Nitrogen ( $\mathrm{as}_{4} \mathrm{Cl}$ ) was added to half of the microcosms to test potential effects of $\mathrm{N}$ limitation on microbial greenhouse gas production. We found that the organic toeslope soils produced more $\mathrm{CO}_{2}$ and $\mathrm{CH}_{4}$, fueled by higher $\mathrm{pH}$ and higher concentrations of water-extractable organic $\mathrm{C}$ (WEOC). Our results also indicate $\mathrm{N}$ limitation on $\mathrm{CO}_{2}$ production in the peat plateau soils but not the toeslope soils. Together these results suggest that the weathering and leaching of ions and nutrients from tundra hillslopes can increase the rate of anaerobic soil organic matter decomposition in downslope soils by (1) increasing the $\mathrm{pH}$ of soil porewater; (2) providing bioavailable WEOC and fermentation products such as acetate; and (3) relieving microbial $\mathrm{N}$ limitation through nutrient runoff. We conclude that the soil geochemistry as mediated by landscape position is an important factor influencing the rate and magnitude of greenhouse gas production in tundra soils.
\end{abstract}

\section{Introduction}

Hillslope topography organizes the distribution of water, energy, and nutrients within landscapes (Burt \& Pinay, 2005). Erosion and selective leaching from areas with elevated topography results in gradients of soil grain size, composition, and chemistry (Milne, 1936; Moore et al., 1993; Wang et al., 2009). This typically results in the accumulation of soil organic matter (SOM), nutrients, and other soil-derived solutes in lowlying areas within watersheds (Creed et al., 2002; Yoo et al., 2006), provided that the soils are hydrologically connected (Hornberger et al., 1994; Stieglitz et al., 2003). In temperate watersheds, slope and elevation have been successfully used to predict stocks of SOM, soil pH, and nutrient concentrations (Creed et al., 2002; Hall \& Olson, 1991; Moore et al., 1993). There is therefore growing interest in representing hillslope processes as subgrid cell heterogeneity in the next generation of Earth system models (Fan et al., 2019).

Accurately representing these processes in the Arctic is particularly important because Arctic soils contain about one third of the total global soil C pool (Hugelius et al., 2014; Schuur et al., 2015) and are severely understudied compared to temperate soils (Metcalfe et al., 2018). There is evidence that similar geochemical gradients exist on Arctic hillslopes, in that nutrients, SOM, and leachable cations accumulate in low-lying soils (Koch et al., 2014; Lev \& King, 1999; Stewart et al., 2014; Yano et al., 2010). However, the presence of permafrost underlying many Arctic soils impedes drainage (Liljedahl et al., 2016). This isolates surface water from deeper flow pathways and increases the hydrological connectivity of the surface soils, potentially strengthening the relationship between the chemistry of the ridge and valley surface soils (Bring et al., 2016). In addition, poor drainage results in saturated soils in upland areas as well as lowlands. Therefore, we expect a trend of increasing $\mathrm{pH}$ and increasing nutrient concentrations in low-lying soils compared to uplands due to erosion, selective leaching, and weathering. 
Previous studies suggest these environmental variables are important regulators of $\mathrm{CO}_{2}$ and $\mathrm{CH}_{4}$ emission from SOM decomposition. For example, rates of anaerobic SOM decomposition in boreal peatlands are consistently observed to increase along gradients of groundwater inputs, from precipitation-fed bogs to mineral-rich fens (Keller et al., 2006; Thormann et al., 1999). This pattern has been attributed both to higher alkalinity via weathering (Ye et al., 2012) and nutrient availability (Bayley et al., 2005; Keller et al., 2006) provided by groundwater inputs. Studies of tundra soils have also indicated that $\mathrm{CH}_{4}$ production is sensitive to pH (Tang et al., 2016; Zheng, Thornton, et al., 2019), nutrients (Philben et al., 2019), and the concentration of labile organic matter (Chen et al., 2018; Yang et al., 2016). Here, we test the hypothesis that the variability in $\mathrm{pH}$ and nutrient availability over a permafrost-affected Arctic hillslope constitutes a landscape-level influence over the rate and pathways of SOM decomposition.

We used laboratory microcosm incubations to investigate differences in potential anaerobic SOM decomposition between two wetland areas within an Arctic watershed near Nome, Alaska. Both are characterized by wet sedge tussock tundra plant community, organic-rich soils, and water tables near the soil surface during the thaw season (Jafarov et al., 2018). However, field observations revealed that their positions on opposite ends of the hillslope result in contrasting porewater geochemistry. We hypothesized that these geochemical differences affect the rates and pathways of anaerobic SOM decomposition, specifically that the transport of leached ions, nutrients, and dissolved organic matter down the hillslope fuels greenhouse gas production in the low-lying toeslope compared to elevated plateau.

\section{Materials and Methods}

\subsection{Study Site}

Soil cores and porewater were collected from two locations within the same watershed in the Teller Road mile 27 site of the Next Generation Ecosystem Experiment (NGEE)-Arctic project (http://ngee-arctic.ornl. gov). The site is located in hilly terrain in the southern Seward Peninsula, Alaska, on a southeast-facing hillslope (Jafarov et al., 2018). One site (hereafter "Plateau") is located on the peat plateau on the top of the hillslope (N64.74512 ${ }^{\circ} \mathrm{W} 165.96668^{\circ}$, WGS84 datum) and the other site ("Toeslope") from the wetland in the toeslope $\left(\mathrm{N} 64.72946^{\circ}\right.$, W165.94465 $)$. Both sites are characterized by tussock tundra, sedge-dominated vegetation, and a water table at or near the soil surface. The depth of the permafrost table varies with hillslope position: the thick peat layers in the peat plateau insulate the soil, resulting in near-surface permafrost, while the active layer is thicker on the hillslope due to greater snow accumulation (Jafarov et al., 2018). The toeslope consists of a collapsed peat plateau wetland that lacks near-surface permafrost ( $>1-\mathrm{m}$ thaw depth in August 2018). In August 2018, the surface water temperature was $10^{\circ} \mathrm{C}$.

\subsection{Soil and Porewater Collection}

Porewater samples were collected from the two sites on five occasions over 3 years ( 9 and 13 September 2016, 9 August 2017, 10 September 2017, and 22 August 2018). Samples were collected using PVC piezometers with slits cut into the sides $10-15 \mathrm{~cm}$ from the bottom to allow soil porewater to percolate in while excluding soil particles. Piezometers were installed at depths of approximately 35 and $70 \mathrm{~cm}$ to sample the organic and mineral soils, respectively. pH was measured in the field using a Hanna Instruments portable pH meter. Subsamples for cation analyses were returned to the laboratory and analyzed using inductively coupled plasma mass spectrometry (ICP-MS). The full data set from these field measurements (Zheng, Philben, et al., 2019) is available in the NGEE-Arctic data portal (https://ngee-arctic.ornl.gov/data).

Cores from the two sites were collected on 1 June 2017 prior to the thawing of the active layer. Frozen cores were collected using an AMS Frozen Soil Powered Auger. Soil cores (5.1-cm diameter) were removed from the unlined auger barrel, wrapped in a plastic sleeve, and cooled with freezer packs. The peat plateau core was drilled at location ${\mathrm{N} 64.74514^{\circ} \text {, W165.96651 }}^{\circ}$ while the toeslope core was from W64.729193 , $\mathrm{W} 165.944072^{\circ}$. The core from the plateau was $76 \mathrm{~cm}$ in length, and the toeslope core was $84 \mathrm{~cm}$. The cores were shipped frozen to Oak Ridge National Laboratory and stored frozen until the start of the incubation. The frozen cores were transferred to an anaerobic chamber and separated into organic and mineral soil layers based on visual inspection. The uppermost layers containing intact vegetation were removed. The 0-38 and 0-34 cm intervals were characterized as organic for the toeslope and the plateau, respectively. Core sections from $38-84 \mathrm{~cm}$ for the toeslope and $61-76 \mathrm{~cm}$ for the plateau were used for the mineral soil. 


\subsection{Microcosm Construction}

The separated cores were cut into small $\left(<0.5 \mathrm{~cm}^{3}\right)$ pieces using an oscillating cutting tool and mixed with a spoon, creating four homogenized samples (organic and mineral soils for the toeslope and the plateau). Soil microcosms were constructed by adding $7 \mathrm{~g}$ (wet soil) to 60-ml serum bottles. One milliliter of either deionized water (control treatment) or $\mathrm{NH}_{4} \mathrm{Cl}$ solution containing $32 \mathrm{mM} \mathrm{N}$ ( $+\mathrm{N}$ treatment) was added to each microcosm, so that the amendment would increase the concentration of inorganic $\mathrm{N}$ by approximately tenfold, based on previous measurements of $\mathrm{N}$ in the toeslope soil (Philben et al., 2019). Three replicate microcosms were prepared for the control and $+\mathrm{N}$ treatments to be incubated at $-2^{\circ} \mathrm{C}$ and $8^{\circ} \mathrm{C}$ for 55 days. In addition, three replicates were constructed for destructive sampling and soil microbial analyses after 15 and 30 days for the $8^{\circ} \mathrm{C}$ treatment only. The microcosms were sealed with blue rubber septa, crimped with aluminum caps, headspace flushed with $\mathrm{N}_{2}$ for $10 \mathrm{~min}$, and transferred to incubators at the appropriate temperature.

\subsection{Greenhouse Gas and Chemical Analysis}

Concentrations of $\mathrm{CO}_{2}$ and $\mathrm{CH}_{4}$ were measured in the headspace of the microcosms every 2 days for the first 2 weeks, then every 5 days thereafter. On each sampling day, $0.5 \mathrm{ml}$ of the headspace was analyzed using gas chromatography, as previously described (Roy Chowdhury et al., 2015). The microcosms incubated at $-2^{\circ} \mathrm{C}$ were kept in a cooler filled with ice packs during analysis to reduce temperature change during the incubation. Headspace $\mathrm{CO}_{2}$ and $\mathrm{CH}_{4}$ concentrations were converted to total gas production using Henry's law based on the water content, temperature of incubation, and measured soil pH (Sander, 2015). Gas production was normalized to per $\mathrm{g}$ dry weight $\left(\mathrm{gdw}^{-1}\right)$ of the soil to compare between soils with variable water contents.

Microcosms were destructively sampled after 15, 30, and 55 days of incubation. In an anaerobic chamber, $2 \mathrm{~g}$ of each soil was extracted with $10 \mathrm{ml}$ of degassed water or $0.1 \mathrm{M} \mathrm{KCl}$ in a $15-\mathrm{ml}$ plastic tube and placed on a reciprocal shaker for $90 \mathrm{~min}$. The soil extracts were centrifuged for $10 \mathrm{~min}$ and filtered through a $0.2-\mu \mathrm{m}$ syringe filter. Aliquots of the $\mathrm{KCl}$ extracts were analyzed immediately for $\mathrm{pH}$ and $\mathrm{Fe}(\mathrm{II})$ using the 1,10-phenanthroline method (Hach method 8146). $\mathrm{NH}_{4}-\mathrm{N}$ concentrations were also analyzed in the $\mathrm{KCl}$ extracts using the colorimetric salicylate and cyanurate method (Hach method 10031).

The water extracts were analyzed for major anion content, low-molecular weight organic acid concentration, ultraviolet-visible (UV-Vis) absorbance, and water-extractable organic C (WEOC). Samples were either analyzed within 3 days of collection or frozen until analysis. Specifically, anions $\left(\mathrm{Cl}^{-}, \mathrm{Br}^{-}, \mathrm{NO}_{3}^{-}\right.$, and $\mathrm{SO}_{4}{ }^{2-}$ ) and organic acids (formate, acetate, propionate, butyrate, and oxalate) were analyzed in the water extracts using ion chromatography using previously established methods (Herndon et al., 2015). The ions were separated using a 4- $\mu \mathrm{m}$ Dionex IonPac AS11-HC column and gradient elution. The eluent was $1 \mathrm{mM}$ $\mathrm{KOH}$ from 0 to $7 \mathrm{~min}$, ramping to $15 \mathrm{mM}$ from 7 to $16 \mathrm{~min}, 30 \mathrm{mM}$ at $25 \mathrm{~min}$, and $60 \mathrm{mM}$ at $33 \mathrm{~min}$. Ions were detected using a Dionex suppressed conductivity detector.

WEOC concentration in the soil extracts were analyzed using a Shimadzu TOC-L analyzer after acidification with $0.1 \% \mathrm{HCl}$ and purging to remove inorganic $\mathrm{C}\left(\mathrm{CO}_{3}{ }^{2-}\right.$ and $\left.\mathrm{HCO}_{3}{ }^{-}\right)$. UV-Vis spectroscopy was also conducted on the water extracts in a 1-cm quartz cuvette over the range 200-800 nm on a Hewlett-Packard 8453 spectrophotometer. Specific UV absorptivity at $254 \mathrm{~nm}\left(\mathrm{SUVA}_{254}\right)$ was calculated as

$$
\mathrm{SUVA}_{254}=100 \times \frac{A_{254}}{[\mathrm{WEOC}]},
$$

where $A_{254}$ indicates the absorbance at $254 \mathrm{~nm}$ and [WEOC] is the WEOC concentration in $\mathrm{mg} \mathrm{C} \mathrm{L}^{-1}$ (Weishaar et al., 2003).

\subsection{FTICR-MS Analysis of DOM Molecular Composition}

Selected samples from Day 0 and Day 55 of the incubation were analyzed using Fourier transform ion cyclotron resonance mass spectrometry (FTICR-MS). The WEOC fraction was subjected to solid-phase extraction (SPE) using Bond Elut PPL cartridges (Agilent) following a method developed by Dittmar et al. (2008). Sample volumes of approximately $5 \mathrm{ml}$ at an average DOC concentration of $35 \pm 20 \mathrm{mg} \mathrm{L}^{-1}$ were acidified with $\mathrm{HCl}$ to $\mathrm{pH} \sim 2$, and loaded onto PPL cartridges (3 ml, $0.1 \mathrm{~g}$ of resin), which were conditioned with 
LC-MS grade methanol (Fisher Scientific) before use. PPL cartridges after desalting were dried by flushing with ultra-high purity nitrogen gas and DOM was eluted out with 1-2 $\mathrm{ml}$ of LC-MS grade methanol. The eluate was then stored at $-20^{\circ} \mathrm{C}$ until FTICR-MS measurements. Samples were analyzed using a Bruker Daltonics 12 Tesla Apex Qe FTICR-MS interfaced to an Apollo electrospray ionization (ESI) source operating in the negative ion mode. Prior to analysis, DOM extracts and PPL blanks were diluted with LC-MS grade water to a methanol:water ratio of 1:1. Samples were injected into the ESI source at an infusion rate of $120 \mu \mathrm{l} \mathrm{h}^{-1}$. The ESI spray current was stable at approximately $20 \mathrm{nA}$ for all sample runs. Ion accumulation in the hexapole was set to $3.0 \mathrm{~s}$, and 300 transients were co-added and digitized with a $4 \mathrm{M}$ Word data acquisition size.

FTICR-MS was externally calibrated with a polyethylene glycol standard and internally calibrated with naturally present homologous series of organic acids detected within samples (Chen et al., 2018). Peaks detected in experimental blanks were removed from the DOM peak list. Molecular formulas were assigned to peaks with a signal to noise $(\mathrm{S} / \mathrm{N})$ ratio above 4 , using the molecular formula calculator from the National High Magnetic Field Laboratory (Molecular Formula Calc v.1.0@ NHML, 1998). The criteria were set as ${ }^{12} \mathrm{C}_{2-50},{ }^{1} \mathrm{H}_{2-120},{ }^{16} \mathrm{O}_{0-30},{ }^{14} \mathrm{~N}_{0-10},{ }^{32} \mathrm{~S}_{0-2}$, and ${ }^{34} \mathrm{P}_{0-1}$, where the subscripts show the range of atoms allowed in each formula. The majority (>95\%) of the assigned formulas were within 0.5-ppm mass accuracy, and all formulas were within 1.0-ppm mass accuracy. Molecules were categorized by compound class using chemical composition metrics as described previously (Chen et al., 2018). Briefly, double bond equivalent (DBE) values are calculated as $\mathrm{DBE}=1+\mathrm{C}-0.5 \mathrm{H}+$ $0.5 \mathrm{~N}+0.5 \mathrm{P}$. The modified aromaticity index $\left(\mathrm{AI}_{\mathrm{mod}}\right)$ was calculated as $\mathrm{AI}_{\text {mod }}=(1+\mathrm{C}-0.5 \mathrm{O}$ $-\mathrm{S}-0.5 \mathrm{~N}-0.5 \mathrm{P}-0.5 \mathrm{H}) /(\mathrm{C}-0.5 \mathrm{O}-\mathrm{N}-\mathrm{S}-\mathrm{P})$, which indicates aromatics when the value is $\geq 0.5$, or condensed aromatics when the value is $\geq 0.67$ (Koch \& Dittmar, 2006).

\subsection{Microbial Community Analysis}

Total DNA was extracted from Day 0 and Day 55 microcosms by using $0.25 \mathrm{~g}$ of wet soil as input to the DNeasy PowerSoil Kit (Qiagen, Germantown, MD, USA) with minor modifications. Prior to bead beating, the samples were incubated in bead-solution at $65^{\circ} \mathrm{C}$ for $5 \mathrm{~min}$. Samples were disrupted by bead beating with a 1600 MiniG (SPEX Sample Prep, Metuchen, NJ, USA) at a setting of 1,500 rpm for $60 \mathrm{~s}$, and the DNA was further purified according to the kit protocol. 16S rRNA genes were amplified in PCR reactions using primers (F515/R806) that target the V4 region of the 16S rRNA gene where reverse PCR primer was barcoded with a 12-base Golay code (Caporaso et al., 2010). The PCR reactions contained 2.5- $\mu$ l Takara Ex Taq PCR buffer, $2-\mu \mathrm{l}$ Takara dNTP mix, $0.7-\mu \mathrm{l}$ Roche BSA $\left(20 \mathrm{mg} \mathrm{ml}^{-1}\right), 0.5 \mu \mathrm{l}$ each of the forward and reverse primers (10 $\mu \mathrm{M}$ final concentration), 0.125- $\mu \mathrm{l}$ Takara Ex Taq Hot Start DNA Polymerase (TaKaRa, Shiga, Japan), 1.0- $\mu$ l genomic DNA (10 ng/reaction), and nuclease-free water in a total volume of $25 \mu \mathrm{l}$. Reactions were held at $98^{\circ} \mathrm{C}$ for $3 \mathrm{~min}$ to denature the DNA, followed by amplification for 25 cycles at $98^{\circ} \mathrm{C}$ for $30 \mathrm{~s}, 52^{\circ} \mathrm{C}$ for $30 \mathrm{~s}$, and $72^{\circ} \mathrm{C}$ for $60 \mathrm{~s}$, and a final extension of $12 \mathrm{~min}$ at $72^{\circ} \mathrm{C}$. Each sample was amplified in triplicate, combined, and purified using the Agencourt AMPure XP PCR purification system (Beckman Coulter, Brea, CA). The purified amplicons were quantified using the Qubit dsDNA HS assay (Invitrogen, Carlsbad, CA, USA). Amplicons were pooled (10 ng/sample) and sequenced on one lane of the Illumina Miseq platform (Illumina Inc, San Diego, CA) resulting in 300 BPPAIRED-END READS. SEQUENCE DATA ARE DEPOSITED AT EUROPEAN NUCLEOTIDE ARCHIVE WITH ACCESSION PRJEB34184.

Paired-end amplicon sequences were overlapped and merged using FLASH (Magoč \& Salzberg, 2011). Quality filtering and demultiplexing were performed as described previously (Bokulich et al., 2013). Sequences were grouped into operational taxonomic units (OTUs) based on 97\% sequence identity, and chimeric sequences were removed using UPARSE (Edgar, 2013). For 16S rRNA gene analysis, OTUs were given taxonomic assignments in QIIME (Caporaso et al., 2010) version 1.7.0 using the RDP classifier (Wang et al., 2007) and the SILVA database 132 (Quast et al., 2013). Phylogenetic trees were created using FastTree (Price et al., 2010) under QIIME's default parameters. All remaining analysis were performed in R version 3.5.1 (Bates et al., 2014; R Core Team, 2019) via use of phyloseq (McMurdie \& Holmes, 2013), vegan (Oksanen et al., 2013), and ggstatsplot (Patil et al., 2019) packages. Amplicon data were proportionally normalized, and $\beta$-diversity was assessed by perMANOVA (Anderson \& Walsh, 2013) using Bray-Curtis distance (Bray \& Curtis, 1957). For multiple comparisons, $p$ values were adjusted via Bonferroni method. 


\subsection{Statistical Analysis}

Porewater chemistry data were fit to a linear mixed effects model using the package lme4 in $\mathrm{R}$ version 3.5.1 (Bates et al., 2014; R Core Team, 2019). Time of incubation (0, 30, or 55 days) and treatment (control or $+\mathrm{N}$ ) were used as fixed factors, and the microcosm replicate was used as a random factor to account for the effects of repeated sampling. The treatment effect was excluded from the model for the inorganic $\left.\mathrm{N}_{\left(\mathrm{NO}_{3}\right.}{ }^{-}+\mathrm{NH}_{4}{ }^{+}\right)$ measurements so that temporal changes in the control treatments were evaluated. For the $\mathrm{CO}_{2}$ and $\mathrm{CH}_{4}$ measurements, the difference between concentrations at 29 and 50 days in the control and $+\mathrm{N}$ treatments were compared using the mixed effects model. Note that the days analyzed are different for the greenhouse gas concentrations and porewater chemistry due to differences in their respective sampling intervals. A separate ANOVA analysis was performed using the $\mathrm{R}$ base package to evaluate differences in initial soil porewater chemistry among the four soils. A significance threshold of $p=0.05$ was used for all statistical analyses.

\section{Results}

\subsection{Porewater Geochemistry of Field Samples}

Comparison of the soil porewater geochemistry over five sampling time points indicated that the average $\mathrm{pH}$ was approximately $1 \mathrm{pH}$ unit higher in the toeslope soils than the plateau soils. This was observed in both the organic soil (6.73 and 5.59, respectively; Figure S1) and in the mineral soils (6.62 and 5.86, respectively). The mean concentration of dissolved cations was also higher and contained a higher proportion of alkaline Earth metals in the toeslope, consistent with the input of weathering products from the hillslope. The mean molar ratio of alkali-to-alkaline Earth cations was 1.34 and 2.20 in the organic and mineral soils of the plateau, respectively, compared to 0.11 and 0.08 in the organic and mineral soils of the toeslope (Figure S1).

\subsection{Rates and Temperature Sensitivity of Greenhouse Gas Production}

$\mathrm{CO}_{2}$ production at both sites was higher in the organic soils than the mineral soils (Figures $1 \mathrm{a}$ and $1 \mathrm{~b}$ ). It was higher in the organic soils of the toeslope than the organic soils of the plateau, especially during the first 15 days of incubation (Figure $1 \mathrm{a} ; p<0.001$ ). $\mathrm{CO}_{2}$ production was not significantly different between the two mineral soils. Similar to the patterns for $\mathrm{CO}_{2}$ production, $\mathrm{CH}_{4}$ production was significantly higher in the toeslope soils than in the plateau soils in the organic $(p=0.047)$ but not the mineral soils (Figures $1 \mathrm{c}$ and 1d), which produced low levels of $\mathrm{CH}_{4}$.

$\mathrm{N}$ addition had contrasting effects on $\mathrm{CO}_{2}$ and $\mathrm{CH}_{4}$ production, as effects on $\mathrm{CO}_{2}$ varied by soil but $\mathrm{CH}_{4}$ production was generally inhibited (Figure 1). $\mathrm{N}$ addition had no effect on $\mathrm{CO}_{2}$ production in either the organic or mineral soils from the toeslope. However, it significantly increased $\mathrm{CO}_{2}$ production in the organic plateau soils $(p=0.010)$. $\mathrm{N}$ addition also increased $\mathrm{CO}_{2}$ production in the plateau mineral soils, but the difference was not significant. In contrast, $\mathrm{N}$ addition generally reduced $\mathrm{CH}_{4}$ production in all soils except for the plateau mineral soil, which exhibited a small but not significant increase. However, the effect on decreasing $\mathrm{CH}_{4}$ production was significant only for the toeslope soils ( $p=0.004$ and 0.024 for the organic and mineral soils, respectively).

\subsection{N Dynamics}

The extractable inorganic $\mathrm{N}$ content (the sum of independently measured $\mathrm{NO}_{3}{ }^{-}$and $\mathrm{NH}_{4}{ }^{+}$) of the organic soil was higher in the toeslope than the plateau soils $\left(0.96\right.$ and $0.63 \mu \mathrm{mol} \mathrm{N} \mathrm{gdw}^{-1}$, respectively; $p=0.020$; Figure 2). The opposite pattern was observed in the mineral soils $(p=0.001)$. However, both plateau soils exhibited net $\mathrm{N}$ immobilization (i.e., the concentration of extractable inorganic $\mathrm{N}$ significantly declined during the incubation; $p<0.001$ ). The toeslope soils both exhibited net $\mathrm{N}$ mineralization (increased extractable inorganic $\mathrm{N}$ ), but the change was not significant. Inorganic $\mathrm{N}$ concentrations in the $+\mathrm{N}$ treatment soils declined during incubation for all four soils, indicating microbial uptake or gaseous loss. The decline in concentration was similar for the two organic soils ( 4.4 and $4.2 \mu \mathrm{mol} \mathrm{gdw}{ }^{-1}$ for the toeslope and plateau, respectively) and was greater than that in the mineral soils (3.3 and $2.3 \mu \mathrm{mol} \mathrm{gdw}^{-1}$, respectively). 

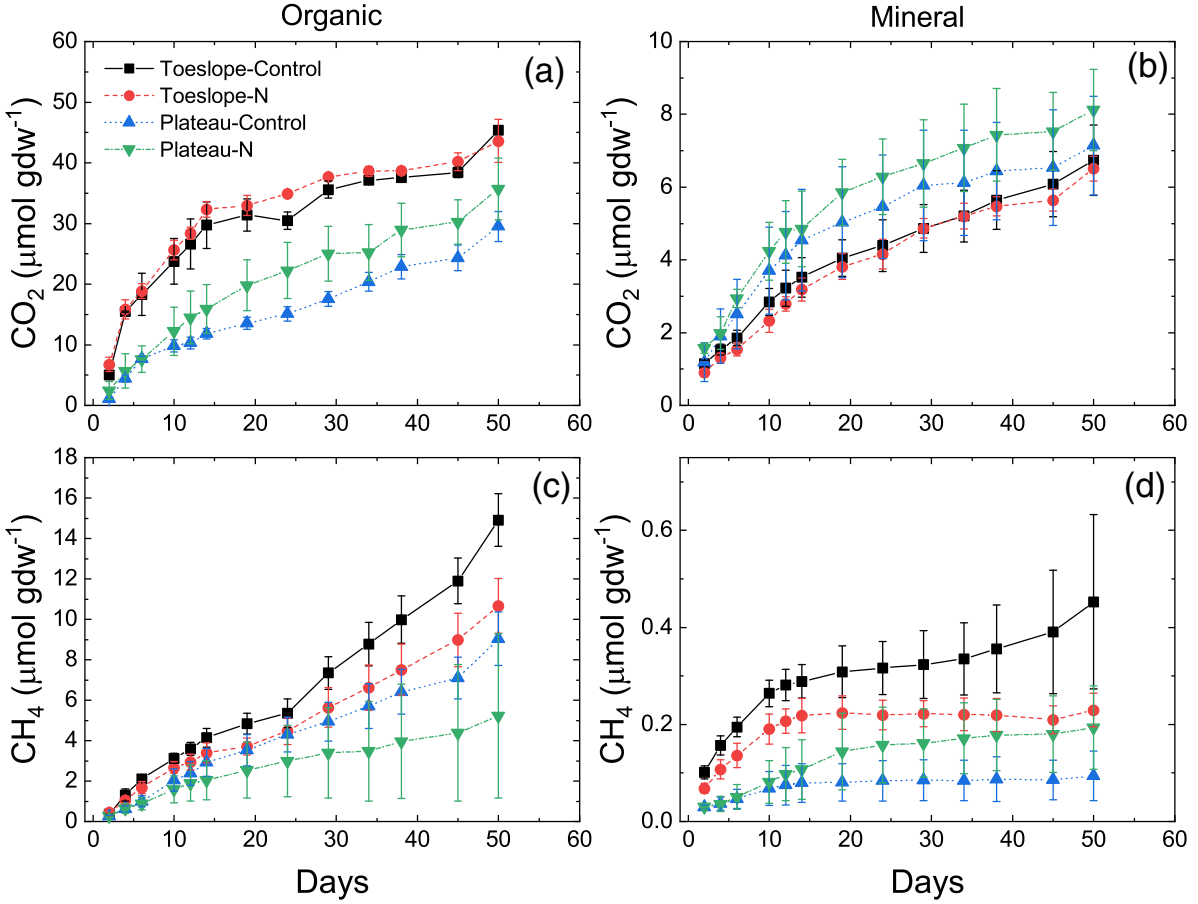

Figure 1. Cumulative (a, b) $\mathrm{CO}_{2}$ and (c, d) $\mathrm{CH}_{4}$ production in the incubations of two contrasting water-saturated tundra soils within a watershed near Nome, Alaska. Incubations were performed with both the organic- and mineral-layer soils either with or without addition of inorganic $\mathrm{N}$ (as $\mathrm{NH}_{4} \mathrm{Cl}$ ). Symbols indicate the mean of three replicates and error bars indicate one standard deviation. Abbreviation "gdw" refers to g dry weight soil.

\subsection{WEOC Quantity and Composition}

Initial concentrations of WEOC were higher in the toeslope than the plateau in both the organic and mineral soils (Figure $3 \mathrm{a}$ and $3 \mathrm{~b} ; p<0.001$ ). WEOC concentrations significantly declined during incubation in all soils $(p<0.001)$, indicating decomposition and immobilization of organic $\mathrm{C}$ was greater than the solubilization of solid-phase SOC. N addition signif-

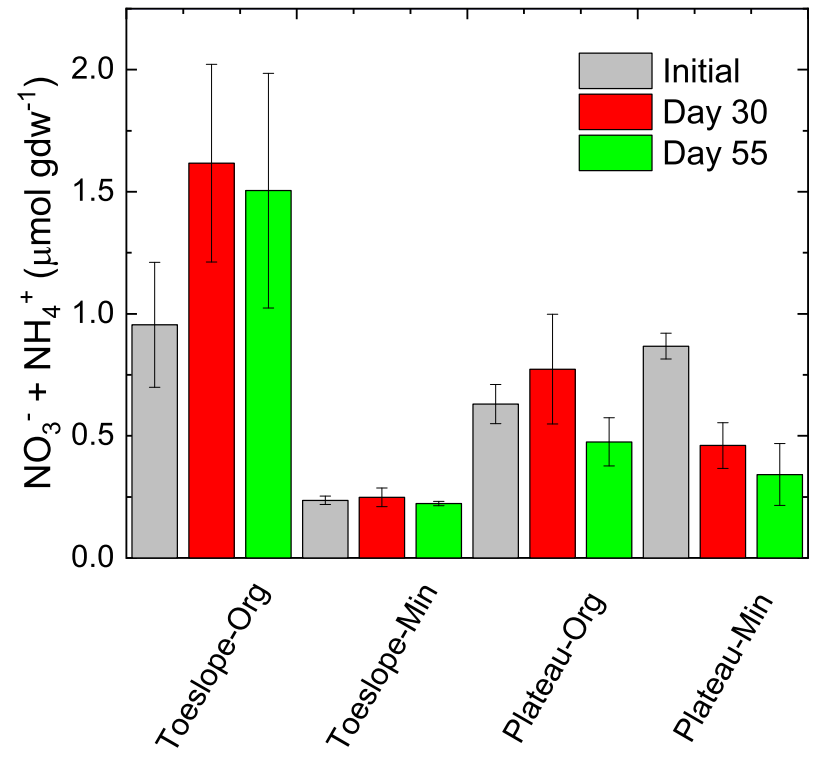

Figure 2. Total extractable inorganic $\mathrm{N}\left(\mathrm{NH}_{4}{ }^{+}+\mathrm{NO}_{3}{ }^{-}\right)$in the initial soils and after 30 and 55 days of incubation. The height of the bars indicates the mean of three replicates, and the error bars indicate one standard deviation. icantly increased the loss of WEOC after 55 days in all soils except for the toeslope organic soil. $\mathrm{SUVA}_{254}$ in the WEOC was slightly higher in the toeslope than the plateau organic soils at the beginning of the experiment ( 0.82 and 0.57 , respectively; $p=0.014$ ), indicating higher aromaticity. SUVA $_{254}$ increased significantly during incubation in all soils except for the organic plateau (Figure 3c). In the mineral soils, the $\mathrm{SUVA}_{254}$ of the WEOC was higher than in the organic soils (2.35 and 1.04 in the toeslope and plateau, respectively; Figure 3d; $p=0.014$ and 0.019, respectively). $\mathrm{N}$ addition resulted in a smaller increase of $\mathrm{SUVA}_{254}$ in the mineral soil control incubations $(p<0.001)$ but not in the organic soils of both sites.

This pattern was also observed in the concentrations of low-molecular weight organic acids, primarily formate, acetate, and propionate. Concentrations were higher in the organic soils of the toeslope than the plateau (Figure 3e). Concentrations in the toeslope organic soil increased throughout the incubation, indicating the production of organic acids via fermentation exceeded their consumption. In the plateau organic soil, concentrations increased from 0 to 30 days but then declined to near the initial concentration after 55 days. Both mineral soils exhibited a net decline in organic acid concentrations by the end of the experiment (Figure 3f). $\mathrm{N}$ addition appeared to have little effect on the organic acid concentrations, and the final concentration was significantly different 

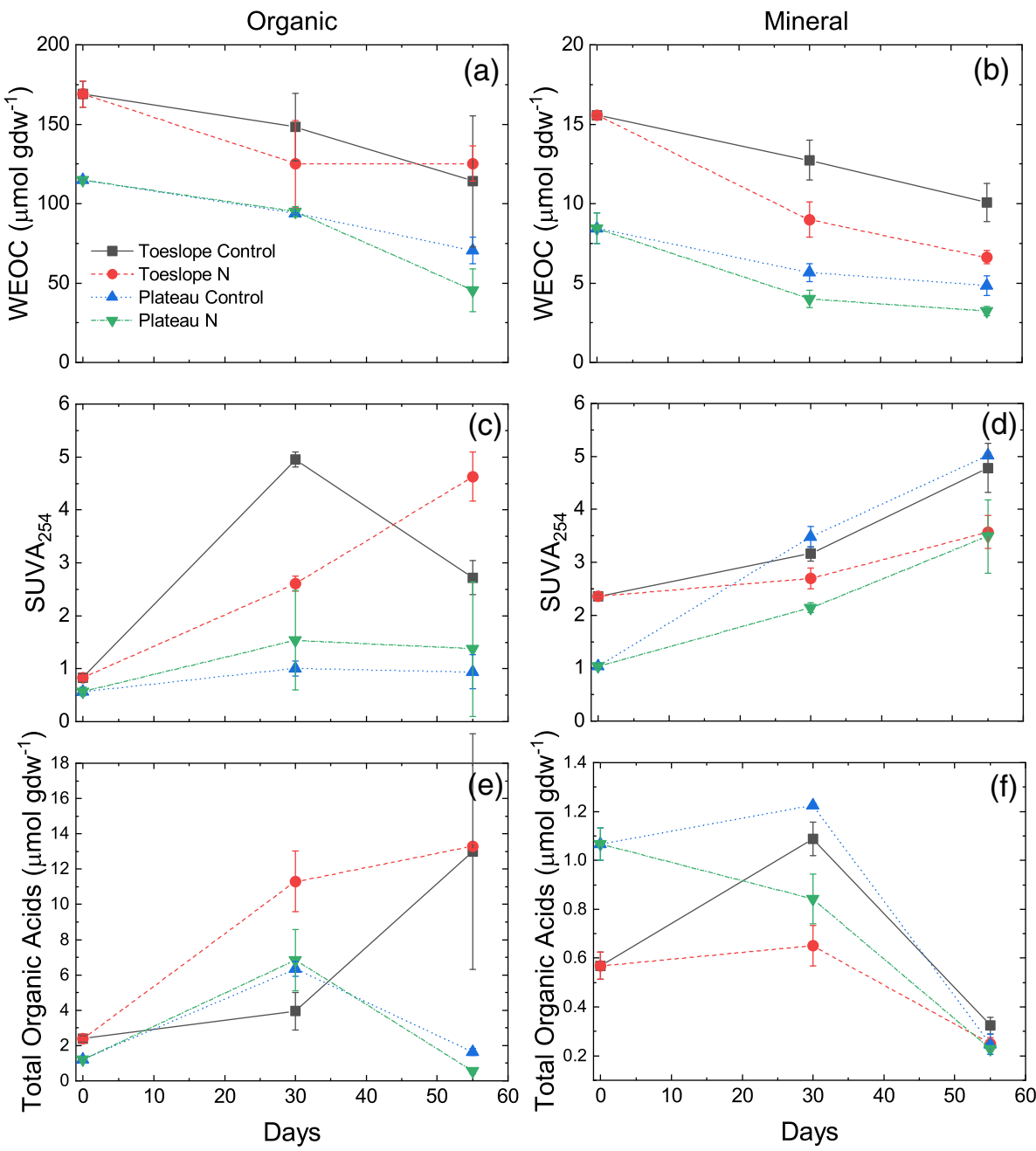

Figure 3. (a, b) Water-extractable organic C (WEOC), (c, d) specific ultraviolet absorbance at $254 \mathrm{~nm}\left(\mathrm{SUVA}_{254}\right)$, and (e, f) total extractable organic acids (sum of formate, acetate, propionate, and butyrate) in the initial soils and after 30 and 55 days of incubation. Symbols indicate the mean of three replicates, and error bars indicate one standard deviation.

only in the plateau organic soils $\left(1.65 \pm 0.20\right.$ and $0.55 \pm 0.16 \mu \mathrm{mol} \mathrm{gdw}^{-1}$ for control and $+\mathrm{N}$ treatments, respectively).

FTICR-MS analysis of the WEOC indicated that formulas corresponding to lignin and condensed aromatic compounds were predominant in all porewater DOC samples (Figure 4 and Table S1). The number of lignin formulas increased in relative abundance during incubation, while condensed aromatics declined. The abundance of $\mathrm{N}$-containing ( $\mathrm{CHON}$ ) and peptide formulas and their response to $\mathrm{N}$ addition varied by site. Between the organic soils, CHON formulas were more abundant in the toeslope than the plateau soils ( $16.9 \%$ and $10.4 \%$ of all formulas, respectively; Figure 4). Following $\mathrm{N}$ addition, the abundance of CHON formulas increased to $20.4 \%$ in the plateau soil, indicating incorporation of the added $\mathrm{N}$ into organic compounds, but did not change in the toeslope soil. Peptide formulas also increased in abundance from $<1 \%$ to $9.7 \%$ in the plateau $\mathrm{N}$-addition incubation but only increased to $2 \%$ in the toeslope soil incubations.

\subsection{Ion Concentrations and Pathways of Anaerobic C Decomposition}

Changes of porewater ion concentrations during the incubations indicated a relatively minor contribution of alternative electron acceptors to the total $\mathrm{C}$ mineralization. $\mathrm{SO}_{4}{ }^{2-}$ concentrations in the toeslope soils declined by $0.02-0.12 \mu \mathrm{mol} \mathrm{gdw}{ }^{-1}$ (Figure S2), indicating that $\mathrm{SO}_{4}{ }^{2-}$ reduction accounted for $<1 \%$ of the 


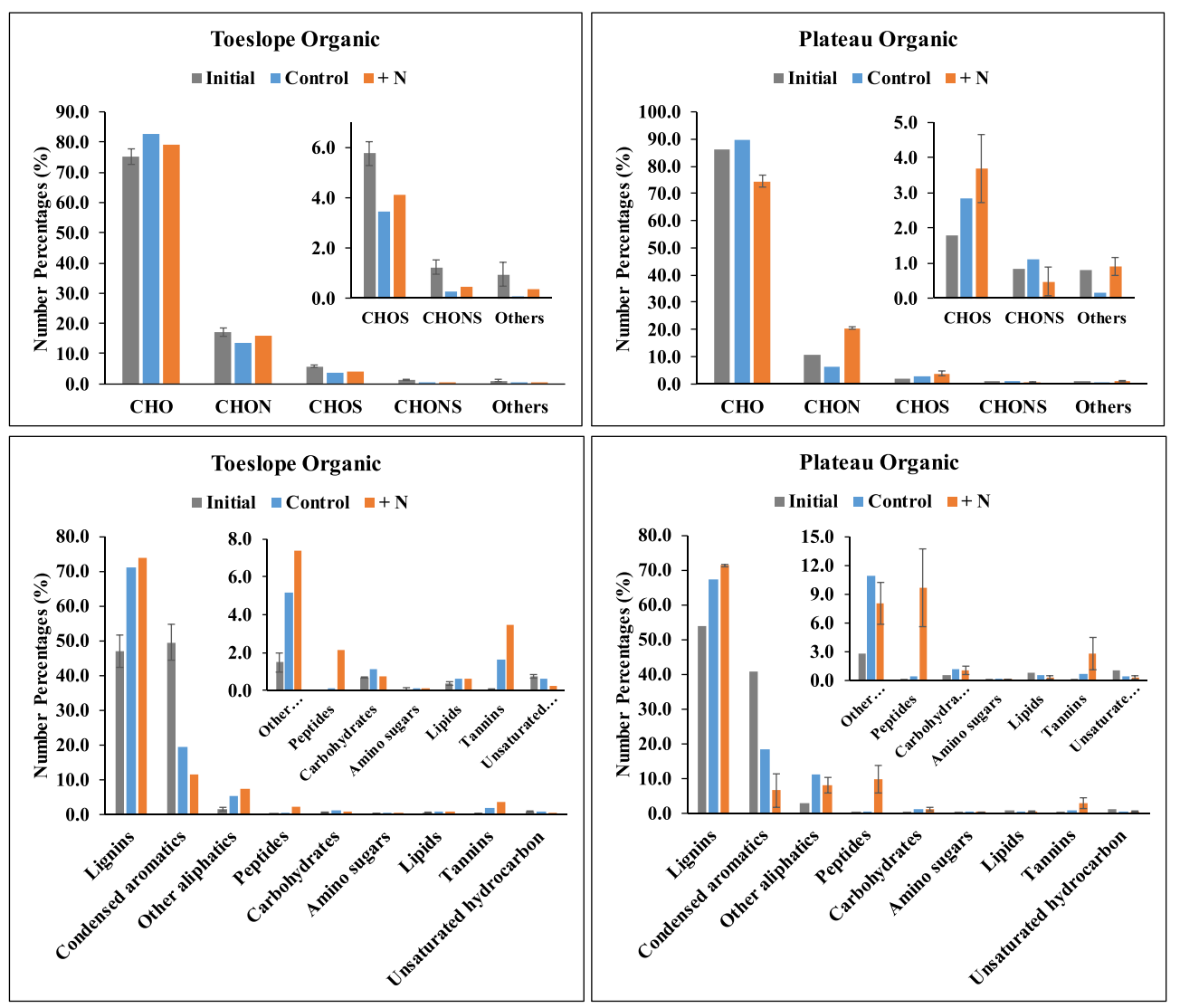

Figure 4. Relative abundance of molecular formulas from FTICR-MS analysis of the WEOC of the organic soils. Error bars indicate the deviation in results between sets of experimental replicates performed for selected samples.

total $\mathrm{C}$ mineralization. In the plateau soils, $\mathrm{SO}_{4}{ }^{2-}$ concentrations increased slightly during incubation, and $\mathrm{SO}_{4}{ }^{2-}$ reduction was not detectable. Denitrification was also minimal, as $\mathrm{NO}_{3}{ }^{-}$declined by $<0.07 \mu \mathrm{mol} \mathrm{gdw}^{-1}$, consistent with low initial $\mathrm{NO}_{3}{ }^{-}$concentrations (data not shown). Reduction of $\mathrm{Fe}(\mathrm{III})$ was detectable in all soils except for the plateau mineral soil, as measured by increasing Fe(II) concentrations in the porewater (Figure S2). The cumulative increase in extractable Fe(II) ranged from 0.4 to $1.4 \mu \mathrm{mol} \mathrm{gdw}{ }^{-1}$ in the control treatments and 0 to $2.9 \mu \mathrm{mol} \mathrm{gdw}^{-1}$ in the $+\mathrm{N}$ treatments, which were not significantly different for any soil. However, Fe(III) reduction accounted for a small fraction of $\mathrm{C}$ mineralization in all soils $(<2 \%)$.

\subsection{Microbial Community Composition}

Microbial communities of toeslope and plateau soils were significantly different from each other $(p=0.005)$ (Figure S3). We also observed a strong effect $(p=0.001)$ where organic and mineral soils in each location clustered separately indicating significant differences in each soil compartment. Proteobacteria, Bacteroides, Acidobacteria, and Chloroflexi were abundant in all soils (Figure 5). Caldiserica were more abundant in the mineral soils than the organic soils. Concentrations of WEOC $(p=0.001)$, propionate $(p=0.001)$, acetate ( $p=0.001)$, and $\mathrm{Fe}(\mathrm{II})(p=0.001)$ were significantly correlated with microbial community structure, especially in plateau soils (Figure S3). Soil pH overall showed a smaller correlation $(p=0.006)$ to the microbial community structure. The effect of nitrogen addition on the microbial community was nuanced. All soils clustered mainly based on their horizons $(p=0.001)$ where impact of nitrogen addition was nested within each horizon $(p=0.001)$ and by itself was not a significant effect $(p=0.881)$.

Nitrogen addition effect was mainly observed as changes in microbial composition in toeslope soils where Firmicutes significantly increased in both organic $(p=0.035)$ and mineral $(p=0.001)$ soils with nitrogen addition (Figure 5). Upon further analysis, we determined that relative abundance of genus 


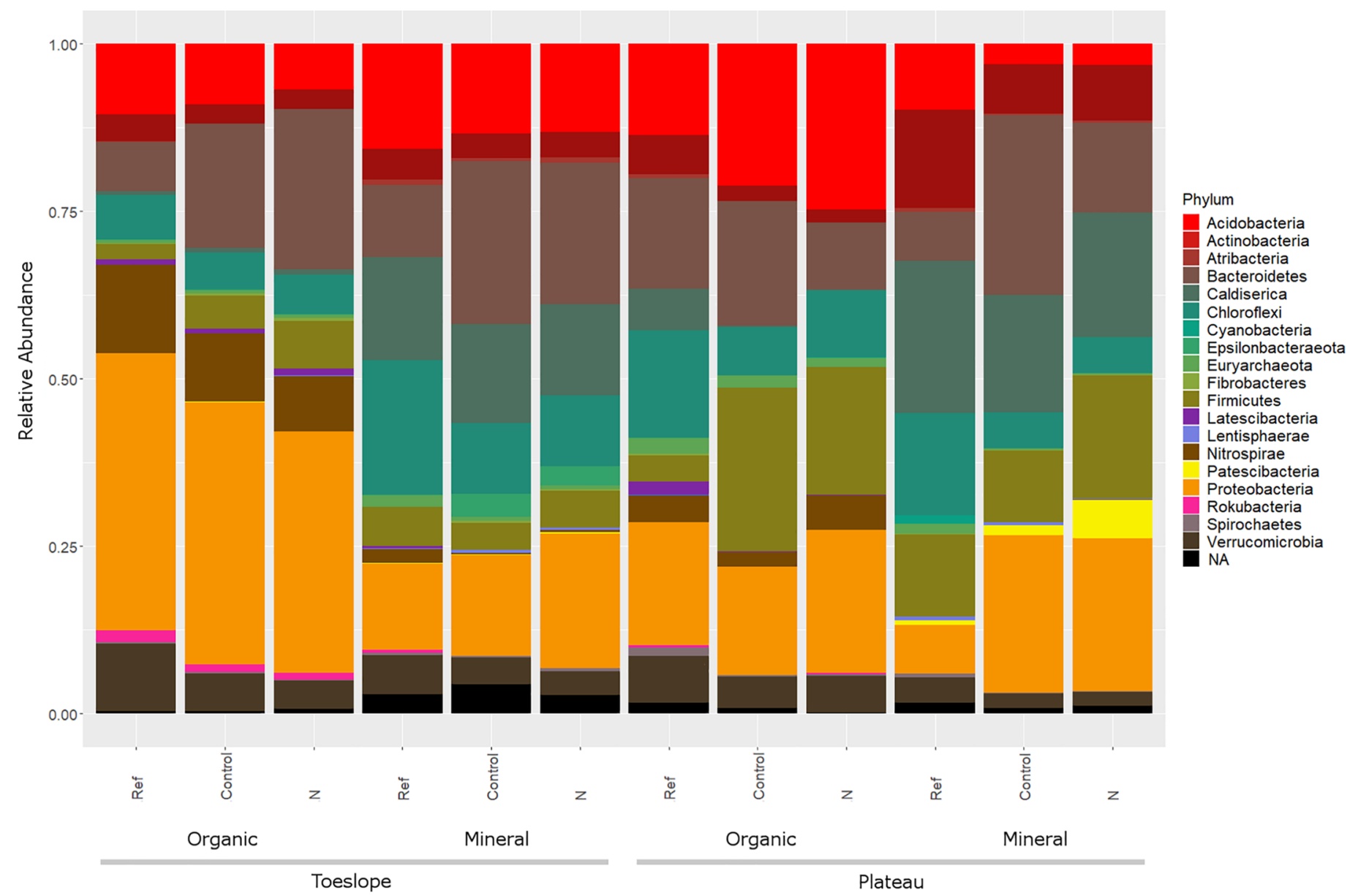

Figure 5. Relative abundance of microbial phyla extracted from the soils before and after incubation. NA: not assigned to a known phylum.

Saccharofermentans increased both in organic $(p=0.025)$ and mineral $(p=0.004)$ soils in response to nitrogen addition (Figures S5 and S6). Additionally, in nitrogen-added mineral soils, we detected significant increase in genus Desulfosporosinus $(p=0.045)$. In organic horizons of toeslope soils, Bacteroides $(p=0.008)$ and Proteobacteria $(p=0.039)$ also increased in their relative abundance but remained unchanged in mineral soils (Figure 5). Plateau soils responded differently to nitrogen addition than toeslope soils where the largest and most significant change observed was the decrease in Bacteroidetes both in organic $(p=0.010)$ and mineral $(p<0.001)$ soils (Figure 5). In both locations, Archaeal populations were dominated by methanogenic archaea of Methanoflorentaceae (former Rice Cluster II) (Adam et al., 2017) (Figure S8) which remained unchanged after nitrogen addition.

\section{Discussion}

\subsection{Effects of Topography on Rates of SOM Decomposition}

Higher exchangeable aluminum and organic acid concentrations reduce the $\mathrm{pH}$ in the peat plateau soil compared to toeslope soils. Preliminary speciation calculations indicate that most of the aluminum, iron, and alkaline earth metal ions in these pore waters are complexed by DOC. Therefore, the cation exchange capacities of DOC and SOM provide an important pH buffer to the soils. Similar precipitation-fed wetlands with no mineral inputs are often acidic due to the accumulation of organic acids resulting from fermentation (Gorham \& Janssens, 1992). Synoptic sampling and analysis of the soil pore waters over 3 years have indicated that the soils from the plateau have sodium bicarbonate-type pore waters, while the toeslope soil pore waters have a calcium-magnesium bicarbonate chemistry with a lower ionic strength. These differences in $\mathrm{pH}$ and geochemical environment are consistent with advanced mineral weathering and high cation 
exchange capacity of peat in the plateau. At the base of the hillslope, however, runoff containing leached alkaline earth metals floods tussock graminoid tundra. Therefore, the difference in $\mathrm{pH}$ between the sites is associated with hillslope position, vegetation, and geomorphology.

Overall, our results show that both $\mathrm{CO}_{2}$ and $\mathrm{CH}_{4}$ production were higher in the organic toeslope soils from the base of the hillslope than in the organic soils from the peat plateau. This is likely in part due to the higher $\mathrm{pH}$ in the toeslope soils, which is a key control on anaerobic SOM decomposition. Empirical estimates of the pH optimum for methanogenesis range from 6.2 to 7.5 (Cao et al., 1995; Meng et al., 2012; Tang et al., 2016). Observations of $\mathrm{CO}_{2}$ and $\mathrm{CH}_{4}$ emission also vary along natural pH gradients in peatlands (Moore \& Knowles, 1990; Zalman et al., 2018), and laboratory incubations show that buffering soils at a higher $\mathrm{pH}$ increases production of both gasses, especially $\mathrm{CH}_{4}$ (Dunfield et al., 1993; Valentine et al., 1994; Ye et al., 2012). This is consistent with our observations of higher rates of $\mathrm{CO}_{2}$ and $\mathrm{CH}_{4}$ production in the circumneutral toeslope soils. However, we observed that the hillslope position affected $\mathrm{CO}_{2}$ much more than $\mathrm{CH}_{4}$ production, resulting in lower $\mathrm{CO}_{2}: \mathrm{CH}_{4}$ ratios in the plateau soils than at the base of the hillslope. This result contrasts with observations that methanogenesis is more sensitive to $\mathrm{pH}$ than other pathways of anaerobic $\mathrm{C}$ mineralization, and suggests that other hillslope differences such as differences in DOC concentration and composition also contribute to the differences in greenhouse gas production.

Porewater DOC represents the fraction of $\mathrm{C}$ directly available to soil microorganisms, and as such is the most important in shaping SOC decomposition dynamics (Chen et al., 2018; Yang et al., 2016). For example, radiocarbon measurements of $\mathrm{CH}_{4}$ in peatlands reflect the young age of the DOC pool rather than the old age of the much larger SOC pool (Chanton et al., 1995, 2008). Accordingly, some biogeochemical models estimate methanogenesis in part as a function of DOC concentration (Cao et al., 1995, 1998; Tian et al., 2010; Xu \& Tian, 2012). WEOC represented a small fraction of the total SOC in both soils $(0.33 \%$ and $0.24 \%$ in the organic soils of the toeslope and plateau, respectively), but the concentrations were higher in the toeslope soils. The higher concentrations of WEOC indicate a larger pool of potentially fermentable substrates and likely contributes to the higher $\mathrm{CO}_{2}$ and $\mathrm{CH}_{4}$ production from these soils.

The patterns of WEOC concentrations during the incubations also suggest limitation of labile $\mathrm{C}$ in the plateau soils. There was a net loss of WEOC during all incubations, indicating that the degradation of DOC by microorganisms (or other uptake/immobilization) exceeded the production of new DOC through the solubilization of solid-phase SOC. Consistent with previous studies (Chen et al., 2018; Yang et al., 2016), the degradation of DOC was selective, as $\mathrm{SUVA}_{254}$ values increased during the incubation. High $\mathrm{SUVA}_{254}$ values are correlated with the abundance of aromatic DOC and are associated with lower $\mathrm{CH}_{4}$ production (D'Andrilli et al., 2010; Hodgkins et al., 2016). The inhibitory effect of highly aromatic DOC on C mineralization could be higher in these anaerobic incubations due to the low activity of phenol oxidase in the absence of oxygen (Freeman et al., 2004; Pind et al., 1994). Therefore, our results indicate selective decomposition of the bioavailable and easily fermentable DOC pool and accumulation of the aromatic fraction. This effect was more pronounced in the plateau soils where initial DOC concentrations were lower. The depletion of easily fermentable $\mathrm{C}$ likely contributes to the lower $\mathrm{CO}_{2}$ and $\mathrm{CH}_{4}$ production in the organic soils.

Limitation of bioavailable DOC was also apparent in the concentrations of low-molecular weight organic acids, the immediate substrates for methanogenesis as well as $\mathrm{Fe}(\mathrm{III})$ and $\mathrm{SO}_{4}{ }^{2-}$ reduction in these soils (Bethke et al., 2011). Models (Tang et al., 2016; Zheng, Thornton, et al., 2019), observations (Christensen et al., 2003; Valentine et al., 1994), and experiments (Herndon et al., 2015; Hershey et al., 2014) indicate that the availability of these substrates limits rates of methanogenesis and anaerobic $\mathrm{C}$ mineralization. The increasing organic acid concentrations in the organic toeslope soils indicated that their production via fermentation exceeded their utilization, and they were therefore not limiting for anaerobic respiration. This was supported by the stable microbial community structure in soils with prevalence of carbohydratefermenting populations such as Firmicutes and Bacteroidetes. In contrast, the pattern of organic acid concentrations and microbial community composition in the mineral horizons suggests substrate limitation of respiration. In the toeslope organic soil, increases in the carbohydrate-fermenting genus Saccharofermentans and Desulfosporosinus, which includes bacteria capable of anaerobic respiration using sulfate, Fe(III), or fumarate as electron acceptors, suggests close coupling of organic acid fermentation and anaerobic respiration (Chen, 2017; Nixon et al., 2017). In plateau mineral soil horizons, observed increases in Group I clostridia (Clostridium sensu stricto) (Gupta \& Gao, 2009) signals the emergence of 
fermentative pathways leading to alcohol, butyrate, acetate, and hydrogen production. In both locations and soil horizons, relative abundance of the dominant methanogenic lineage Methanoflorentaceae (former Rice Cluster II) showed no significant change with incubation, yet we observed different $\mathrm{CH}_{4}$ production rates. The hydrogenotrophic methanogen candidatus Methanoflorens stordalenmirensis was identified as the predominant methanogen in a northern Sweden permafrost thaw site (Mondav et al., 2014). The strong correlation of WEOC and organic acid concentrations with the overall microbial community composition (Figure S3) provides other lines of evidence that substrate availability was a key control on microbial growth. Therefore, we conclude that continued bioavailability of WEOC (Figure 3) in the toeslope supported a higher rate of fermentation, in turn fueling higher rates of $\mathrm{CO}_{2}$ and $\mathrm{CH}_{4}$ production.

\subsection{Greater Microbial N Limitation in the Plateau Soils}

Several lines of evidence indicate that the plateau soils were more $\mathrm{N}$ limited than the toeslope soils, especially in the organic soil. First, the concentration of extractable inorganic $\mathrm{N}\left(\mathrm{NO}_{3}{ }^{-}+\mathrm{NH}_{4}{ }^{+}\right)$was higher in the organic soils of the toeslope than the plateau. Second, extractable inorganic $\mathrm{N}$ increased during the incubation of the toeslope organic control soils, indicating net $\mathrm{N}$ mineralization. This is consistent with previous observations that net $\mathrm{N}$ mineralization is generally higher in soils in lower topographic positions (Giblin et al., 1991; Nadelhoffer et al., 1991). In contrast to the toeslope organic soil, both plateau soils exhibited declining inorganic $\mathrm{N}$ concentrations during incubation, indicating either net $\mathrm{N}$ immobilization or gaseous $\mathrm{N}$ losses. This observation is consistent with greater $\mathrm{N}$ availability in the toeslope soils. The increase in CHON and peptide formulas following $\mathrm{N}$ addition in the plateau but not the toeslope organic soils by FTICR-MS analysis also demonstrates that the added $\mathrm{N}$ was assimilated to a greater degree in the plateau soils, consistent with greater microbial $\mathrm{N}$ limitation. Finally, $\mathrm{N}$ addition increased $\mathrm{CO}_{2}$ production in the organic plateau soils but not the toeslope soils, further demonstrating that SOM decomposition was N limited in the former but not the latter.

Although we do not have direct evidence of the sources of $\mathrm{N}$ to the toeslope soils, these patterns are consistent with leaching and downslope transport of inorganic and labile organic $\mathrm{N}$ down the hillslope. The differences in $\mathrm{pH}$, ion composition, and alkali-to-alkaline earth metal ratio of the porewater demonstrate distinct sources of water inputs, indicating the water in the toeslope soils is derived from hillslope runoff. Previous studies have demonstrated that nutrients (including $\mathrm{N}$ ) are transported downslope and accumulate in low-lying areas (Stewart et al., 2014). Our results extend these findings to tundra landscapes and demonstrate that they cause associated differences in anaerobic SOM decomposition. The hillslope gradient in decomposition is similar to the hydrological fen-bog gradient in peatlands, in which wetlands with higher $\mathrm{pH}$ and nutrient availability are associated with higher rates of anaerobic SOM decomposition, especially $\mathrm{CH}_{4}$ production (Keller et al., 2006; Thormann et al., 1999; Ye et al., 2012).

Our experiments utilized cores collected in early June, before the Arctic growing season. N limitation in tundra soils is observed to be highest at the peak of the growing season, when plants and microorganisms are competing for available $\mathrm{N}$ (Melle et al., 2015). These microcosm incubation experiments are therefore conservative estimates of the potential $\mathrm{N}$ limitation of SOM decomposition; the lack of effect of $\mathrm{N}$ addition on $\mathrm{CO}_{2}$ production in the toeslope soils does not preclude $\mathrm{N}$ limitation during the summer, as has been observed previously (Philben et al., 2019). However, our results are consistent with relatively greater $\mathrm{N}$ limitation in the plateau soils compared to the toeslope.

In contrast to the organic soils, there was no evidence that $\mathrm{N}$ availability in the mineral soils differed between the plateau and the toeslope. There was no difference in initial extractable $\mathrm{N}$ content. No net $\mathrm{N}$ mineralization was observed in the toeslope soils, and $\mathrm{N}$ addition did not significantly increase $\mathrm{CO}_{2}$ production. This indicates that the apparent microbial $\mathrm{N}$ limitation was limited to the organic plateau soil. Mineral soils could therefore experience a smaller increase in $\mathrm{CO}_{2}$ production in response to increased N availability.

While $\mathrm{N}$ addition stimulated $\mathrm{CO}_{2}$ production in the organic plateau soil, it consistently decreased $\mathrm{CH}_{4}$ production in all but one soil (the plateau mineral soil). This likely results from suppression of methanogenesis due to reduced $\mathrm{pH}$. The $\mathrm{pH}$ optimum for methanogenesis is between 6 and 7 , and the slope of the response function appears to be steeper than that of $\mathrm{CO}_{2}$ production due to the specificity of the microbes and enzymes involved (Ye et al., 2012). The $\mathrm{pH}$ of the $\mathrm{KCl}$ extracts following incubation was consistently lower in the microcosms with added $\mathrm{NH}_{4} \mathrm{Cl}$ compared to the control microcosms. This was in part due to the 
weakly acidic nature of the $\mathrm{NH}_{4} \mathrm{Cl}$ solution ( $\left.\mathrm{pH} \sim 5.7\right)$ and likely due to the effects of increased proton production via fermentation, especially in the plateau soils. The lower $\mathrm{pH}$ in the $\mathrm{N}$-fertilized treatments could result in reduced $\mathrm{CH}_{4}$ production despite other indicators of microbial $\mathrm{N}$ limitation, emphasizing the complex feedbacks regulating $\mathrm{CH}_{4}$ production.

\section{Conclusions}

We observed major differences in the rates of greenhouse gas production in two wetland areas within the same watershed. Despite surface similarities between the wetland areas, the toeslope organic soil produced significantly more $\mathrm{CO}_{2}$ and $\mathrm{CH}_{4}$ than the plateau soil due to higher availability of labile DOC and higher $\mathrm{pH}$ than the plateau soils during anaerobic incubation. Our results also indicate that inorganic $\mathrm{N}$ concentrations were lower and soil $\mathrm{C}$ decomposition was more $\mathrm{N}$ limited in the plateau soils than the toeslope soils, which exhibited net $\mathrm{N}$ mineralization while the plateau soils had net $\mathrm{N}$ immobilization. Examination of the changes in porewater geochemistry, soil microbial community, and response to $\mathrm{N}$ addition indicate that the differences are due to a combination of (1) higher $\mathrm{pH}$ due to leaching of mineral weathering products from the hillslope; (2) higher $\mathrm{N}$ availability for microorganisms; and (3) higher availability of fermentable DOC, which provided an ample supply of labile organic substrates throughout the incubations in the toeslope soils. These results demonstrate that topographic position, geochemical environment, and hydrologic flow are important considerations to predict the fate of SOC in thawing permafrost.

\section{Acknowledgments}

The authors declare no financial conflicts of interest. The full data set for the incubation experiments (Philben et al., 2020) and the mass spectrometry results (Chen et al., 2020) can be found on the NGEE-Arctic Data Portal (https://ngee-arctic.ornl.gov/data). We thank Xiangping Yin for ICP-MS analyses of samples and technical support in laboratory. Xujun Liang and Jianqiu Zheng assisted constructing the soil microcosms. The Next Generation Ecosystem Experiments (NGEE-Arctic) project is supported by the Office of Biological and Environmental Research in the Department of Energy (DOE) Office of Science. Oak Ridge National Laboratory is managed by UT-Battelle LLC for DOE under contract DE-AC0500OR22725.

\section{References}

Adam, P. S., Borrel, G., Brochier-Armanet, C., \& Gribaldo, S. (2017). The growing tree of Archaea: New perspectives on their diversity, evolution and ecology. The ISME Journal, 11(11), 2407-2425. https://doi.org/10.1038/ismej.2017.122

Anderson, M. J., \& Walsh, D. C. I. (2013). PERMANOVA, ANOSIM, and the Mantel test in the face of heterogeneous dispersions: What null hypothesis are you testing?Ecological Monographs, 83(4), 557-574. https://doi.org/10.1890/12-2010.1

Bates, D., Maechler, M., Bolker, B., \& Walker, S. (2014). lme4: Linear mixed-effects models using Eigen and S4. R package version 1.1-7.

Bayley, S. E., Thormann, M. N., \& Szumigalski, A. R. (2005). Nitrogen mineralization and decomposition in western boreal bog and fen peat. Ecoscience, 12(4), 455-465. https://doi.org/10.2980/i1195-6860-12-4-455.1

Bethke, C. M., Sanford, R. A., Kirk, M. F., Jin, Q., \& Flynn, T. M. (2011). The thermodynamic ladder in geomicrobiology. American Journal of Science, 311(3), 183-210. https://doi.org/10.2475/03.2011.01

Bokulich, N. A., Subramanian, S., Faith, J. J., Gevers, D., Gordon, J. I., Knight, R., et al. (2013). Quality-filtering vastly improves diversity estimates from Illumina amplicon sequencing. Nature Methods, 10(1), 57-59. https://doi.org/10.1038/nmeth.2276

Bray, J. R., \& Curtis, J. T. (1957). An ordination of the upland forest communities of southern Wisconsin. Ecological Monographs, 27(4), 325-349. https://doi.org/10.2307/1942268

Bring, A., Fedorova, I., Dibike, Y., Hinzman, L., Mård, J., Mernild, S. H., et al. (2016). Arctic terrestrial hydrology: A synthesis of processes, regional effects, and research challenges. Journal of Geophysical Research: Biogeosciences, 121, 621-649. https://doi.org/10.1002/ 2015JG003131

Burt, T. P., \& Pinay, G. (2005). Linking hydrology and biogeochemistry in complex landscapes. Progress in Physical Geography: Earth and Environment, 29(3), 297-316. https://doi.org/10.1191/0309133305pp450ra

Cao, M., Dent, J. B., \& Heal, O. W. (1995). Modeling methane emissions from rice paddies. Global Biogeochemical Cycles, 9(2), $183-195$. https://doi.org/10.1029/94GB03231

Cao, M., Gregson, K., \& Marshall, S. (1998). Global methane emission from wetlands and its sensitivity to climate change. Atmospheric Environment, 32(19), 3293-3299. https://doi.org/10.1016/S1352-2310(98)00105-8

Caporaso, J. G., Kuczynski, J., Stombaugh, J., Bittinger, K., Bushman, F. D., Costello, E. K., et al. (2010). QIIME allows analysis of highthroughput community sequencing data. Nature Methods, 7(5), 335-336. https://doi.org/10.1038/nmeth.f.303

Chanton, J. P., Bauer, J. E., Glaser, P. A., Siegel, D. I., Kelley, C. A., Tyler, S. C., et al. (1995). Radiocarbon evidence for the substrates supporting methane formation within northern Minnesota peatlands. Geochimica et Cosmochimica Acta, 59(17), 3663-3668. https://doi. org/10.1016/0016-7037(95)00240-Z

Chanton, J. P., Glaser, P. H., Chasar, L. S., Burdige, D. J., Hines, M. E., Siegel, D. I., et al. (2008). Radiocarbon evidence for the importance of surface vegetation on fermentation and methanogenesis in contrasting types of boreal peatlands. Global Biogeochemical Cycles, 22, GB4022. https://doi.org/10.1029/2008GB003274

Chen, H., Philben, M., Graham, D., \& Gu, B. (2020). ESI-FTICR-MS Analysis of Organic Matter during Incubations with Nitrogen Addition, Teller Road Site, Seward Peninsula, Alaska. Oak Ridge, TN: Next Generation Ecosystem Experiments Arctic Data Collection, Oak Ridge National Laboratory, U.S. Department of Energy. https://doi.org/10.5440/1631035

Chen, H., Yang, Z., Chu, R. K., Tolic, N., Liang, L., Graham, D. E., et al. (2018). Molecular insights into Arctic soil organic matter degradation under warming. Environmental Science \& Technology, 52(8), 4555-4564. https://doi.org/10.1021/acs.est.7b05469

Chen, S. (2017). Saccharofermentans. In Bergey's manual of systematics of Archaea and bacteria (pp. 1-5). Hoboken, NJ: John Wiley \& Sons, Inc. https://doi.org/10.1002/9781118960608.gbm01450

Christensen, T. R., Ekberg, A., Ström, L., Mastepanov, M., Panikov, N., Öquist, M., et al. (2003). Factors controlling large scale variations in methane emissions from wetlands. Geophysical Research Letters, 30(7), 1414. https://doi.org/10.1029/2002GL016848

Creed, I. F., Trick, C. G., Band, L. E., \& Morrison, I. K. (2002). Characterizing the spatial pattern of soil carbon and nitrogen pools in the Turkey Lakes Watershed: A comparison of regression techniques. Water, Air, \& Soil Pollution: Focus, 2(1), 81-102. https://doi.org/ 10.1023/A:1015886308016

D'Andrilli, J., Chanton, J. P., Glaser, P. H., \& Cooper, W. T. (2010). Characterization of dissolved organic matter in northern peatland soil porewaters by ultra high resolution mass spectrometry. Organic Geochemistry, 41(8), 791-799. https://doi.org/10.1016/j. orggeochem.2010.05.009 
Dittmar, T., Koch, B., Hertkorn, N., \& Kattner, G. (2008). A simple and efficient method for the solid-phase extraction of dissolved organic matter (SPE-DOM) from seawater. Limnology and Oceanography: Methods, 6(6), 230-235.

Dunfield, P., Knowles, R., Dumont, R., \& Moore, T. R. (1993). Methane production and consumption in temperate and subarctic peat soils: Response to temperature and pH. Soil Biology and Biochemistry, 25(3), 321-326. https://doi.org/10.1016/0038-0717(93)90130-4

Edgar, R. C. (2013). UPARSE: Highly accurate OTU sequences from microbial amplicon reads. Nature Methods, 10(10), 996-998. https:// doi.org/10.1038/nmeth.2604

Fan, Y., Clark, M., Lawrence, D. M., Swenson, S., Band, L. E., Brantley, S. L., et al. (2019). Hillslope hydrology in global change research and Earth system modeling. Water Resources Research, 55, 1737-1772. https://doi.org/10.1029/2018WR023903

Freeman, C., Ostle, N. J., Fenner, N., \& Kang, H. (2004). A regulatory role for phenol oxidase during decomposition in peatlands. Soil Biology and Biochemistry, 36(10), 1663-1667. https://doi.org/10.1016/j.soilbio.2004.07.012

Giblin, A. E., Nadelhoffer, K. J., Shaver, G. R., Laundre, J. A., \& McKerrow, A. J. (1991). Biogeochemical diversity along a riverside toposequence in Arctic Alaska. Ecological Monographs, 61(4), 415-435. https://doi.org/10.2307/2937049

Gorham, E., \& Janssens, J. A. (1992). Concepts of fen and bog re-examined in relation to bryophyte cover and the acidity of surface waters. Acta Societatis Botanicorum Poloniae, 61(1), 8. https://doi.org/10.5586/asbp.1992.001

Gupta, R. S., \& Gao, B. (2009). Phylogenomic analyses of clostridia and identification of novel protein signatures that are specific to the genus Clostridiumsensu stricto (cluster I). International Journal of Systematic and Evolutionary Microbiology, 59(2), 285-294. https://doi. org/10.1099/ijs.0.001792-0

Hall, G. F., \& Olson, C. G. (1991). Predicting variability of soils from landscape models. Spatial Variabilities of Soils and Landforms, 9-24.

Herndon, E. M., Mann, B. F., Roy Chowdhury, T., Yang, Z., Wullschleger, S. D., Graham, D., et al. (2015). Pathways of anaerobic organic matter decomposition in tundra soils from Barrow, Alaska. Journal of Geophysical Research: Biogeosciences, 120, 2345-2359. https://doi. org/10.1002/2015JG003147

Hershey, A. E., Northington, R. M., \& Whalen, S. C. (2014). Substrate limitation of sediment methane flux, methane oxidation and use of stable isotopes for assessing methanogenesis pathways in a small arctic lake. Biogeochemistry, 117(2-3), 325-336. https://doi.org/ 10.1007/s10533-013-9864-y

Hodgkins, S. B., Tfaily, M. M., Podgorski, D. C., McCalley, C. K., Saleska, S. R., Crill, P. M., et al. (2016). Elemental composition and optical properties reveal changes in dissolved organic matter along a permafrost thaw chronosequence in a subarctic peatland. Geochimica et Cosmochimica Acta, 187, 123-140. https://doi.org/10.1016/j.gca.2016.05.015

Hornberger, G. M., Bencala, K. E., \& McKnight, D. M. (1994). Hydrological controls on dissolved organic carbon during snowmelt in the Snake River near Montezuma, Colorado. Biogeochemistry, 25(3), 147-165. https://doi.org/10.1007/BF00024390

Hugelius, G., Strauss, J., Zubrzycki, S., Harden, J. W., Schuur, E. A. G., Ping, C.-L., et al. (2014). Estimated stocks of circumpolar permafrost carbon with quantified uncertainty ranges and identified data gaps. Journal of Geophysical Research: Biogeosciences, 11, $6573-6593$. https://doi.org/10.5194/bg-11-6573-2014

Jafarov, E. E., Coon, E. T., Harp, D. R., Wilson, C. J., Painter, S. L., Atchley, A. L., \& Romanovsky, V. E. (2018). Modeling the role of preferential snow accumulation in through talik development and hillslope groundwater flow in a transitional permafrost landscape. Environmental Research Letters, 13(10), 105006. https://doi.org/10.1088/1748-9326/aadd30

Keller, J. K., Bauers, A. K., Bridgham, S. D., Kellogg, L. E., \& Iversen, C. M. (2006). Nutrient control of microbial carbon cycling along an ombrotrophic-minerotrophic peatland gradient. Journal of Geophysical Research, 111, G03006. https://doi.org/10.1029/ 2005JG000152

Koch, B. P., \& Dittmar, T. (2006). From mass to structure: An aromaticity index for high-resolution mass data of natural organic matter. Rapid Communications in Mass Spectrometry, 20(5), 926-932. https://doi.org/10.1002/rcm.2386

Koch, J. C., Gurney, K., \& Wipfli, M. S. (2014). Morphology-dependent water budgets and nutrient fluxes in Arctic thaw ponds. Permafrost and Periglacial Processes, 25(2), 79-93. https://doi.org/10.1002/ppp.1804

Lev, A., \& King, R. H. (1999). Spatial variation of soil development in a high arctic soil landscape: Truelove Lowland, Devon Island, Nunavut, Canada. Permafrost and Periglacial Processes, 10(3), 289-307. https://doi.org/10.1002/(SICI)1099-1530(199907/09)10:3<289:: AID-PPP319>3.0.CO;2-Z

Liljedahl, A. K., Boike, J., Daanen, R. P., Fedorov, A. N., Frost, G. V., Grosse, G., et al. (2016). Pan-Arctic ice-wedge degradation in warming permafrost and its influence on tundra hydrology. Nature Geoscience, 9(4), 312-318. https://doi.org/10.1038/ngeo2674

Magoč, T., \& Salzberg, S. L. (2011). FLASH: Fast length adjustment of short reads to improve genome assemblies. Bioinformatics, 27(21), 2957-2963. https://doi.org/10.1093/bioinformatics/btr507

McMurdie, P. J., \& Holmes, S. (2013). phyloseq: An R package for reproducible interactive analysis and graphics of microbiome census data. PLoS ONE, 8(4), e61217. https://doi.org/10.1371/journal.pone.0061217

Melle, C., Wallenstein, M., Darrouzet-Nardi, A., \& Weintraub, M. N. (2015). Microbial activity is not always limited by nitrogen in Arctic tundra soils. Soil Biology and Biochemistry, 90, 52-61. https://doi.org/10.1016/j.soilbio.2015.07.023

Meng, L., Hess, P. G. M., Mahowald, N. M., Yavitt, J. B., Riley, W. J., Subin, Z. M., et al. (2012). Sensitivity of wetland methane emissions to model assumptions: Application and model testing against site observations. Journal of Geophysical Research: Biogeosciences, 9 , 2793-2819. https://doi.org/10.5194/bg-9-2793-2012

Metcalfe, D. B., Hermans, T. D., Ahlstrand, J., Becker, M., Berggren, M., Björk, R. G., et al. (2018). Patchy field sampling biases understanding of climate change impacts across the Arctic. Nature Ecology \& Evolution, 2(9), 1443-1448. https://doi.org/10.1038/s41559-0180612-5

Milne, G. (1936). Normal erosion as a factor in soil profile development. Nature, 138(3491), 548-549.

Mondav, R., Woodcroft, B. J., Kim, E.-H., McCalley, C. K., Hodgkins, S. B., Crill, P. M., et al. (2014). Discovery of a novel methanogen prevalent in thawing permafrost. Nature Communications, 5(1), 1, 3212-7. https://doi.org/10.1038/ncomms4212

Moore, I. D., Gessler, P. E., Nielsen, G. A. E., \& Peterson, G. A. (1993). Soil attribute prediction using terrain analysis. Soil Science Society of America Journal, 57(2), 443-452. https://doi.org/10.2136/sssaj1993.03615995005700020026x

Moore, T. R., \& Knowles, R. (1990). Methane emissions from fen, bog and swamp peatlands in Quebec. Biogeochemistry, 11(1), 45-61. https://doi.org/10.1007/BF00000851

Nadelhoffer, K. J., Giblin, A. E., Shaver, G. R., \& Laundre, J. A. (1991). Effects of temperature and substrate quality on element mineralization in six arctic soils. Ecology, 72(1), 242-253. https://doi.org/10.2307/1938918

Nixon, S. L., Telling, J. P., Wadham, J. L., \& Cockell, C. S. (2017). Viable cold-tolerant iron-reducing microorganisms in geographically diverse subglacial environments. Journal of Geophysical Research: Biogeosciences, 14, 1445-1455. https://doi.org/10.5194/bg-14-1445-2017

Oksanen, J., Blanchet, F. G., Kindt, R., Legendre, P., Minchin, P. R., O'hara, R. B., et al. (2013). Package 'vegan.' Community Ecology Package, Version 2(9), 1-295. 
Patil, I., Powell, C., Beasley, W., \& Heck, D. (2019). ggstatsplot: Major restructuring of the entire package. Zenodo. https://doi.org/10.5281/ zenodo. 3382322

Philben, M., Graham, D., \& Gu, B. (2020). Greenhouse Gas Production and Soil Chemistry in Anaerobic Soil Microcosm Incubations after Nitrogen Addition, Teller Road Site, Seward Peninsula, 2018-2019. Oak Ridge, TN: Next Generation Ecosystem Experiments Arctic Data Collection, Oak Ridge National Laboratory, U.S. Department of Energy. https://doi.org/10.5440/1529003

Philben, M., Zheng, J., Bill, M., Heikoop, J. M., Perkins, G., Yang, Z., et al. (2019). Stimulation of anaerobic organic matter decomposition by subsurface organic N addition in tundra soils. Soil Biology and Biochemistry, 130, 195-204. https://doi.org/10.1016/j. soilbio.2018.12.009

Pind, A., Freeman, C., \& Lock, M. A. (1994). Enzymic degradation of phenolic materials in peatlands-Measurement of phenol oxidase activity. Plant and Soil, 159(2), 227-231. https://doi.org/10.1007/BF00009285

Price, M. N., Dehal, P. S., \& Arkin, A. P. (2010). FastTree 2-Approximately maximum-likelihood trees for large alignments. PLoS ONE, 5(3), e9490. https://doi.org/10.1371/journal.pone.0009490

Quast, C., Pruesse, E., Yilmaz, P., Gerken, J., Schweer, T., Yarza, P., et al. (2013). The SILVA ribosomal RNA gene database project: Improved data processing and web-based tools. Nucleic Acids Research, 41(Database issue), D590-D596. https://doi.org/10.1093/nar/ gks1219

R Core Team (2019). R: A language and environment for statistical computing. Vienna, Austria: R Foundation for Statistical Computing Retrieved from https://www.R-project.org/

Roy Chowdhury, T., Herndon, E. M., Phelps, T. J., Elias, D. A., Gu, B., Liang, L., et al. (2015). Stoichiometry and temperature sensitivity of methanogenesis and $\mathrm{CO}_{2}$ production from saturated polygonal tundra in Barrow, Alaska. Global Change Biology, 21(2), 722-737. https:// doi.org/10.1111/gcb.12762

Sander, R. (2015). Compilation of Henry's law constants (version 4.0) for water as solvent. Atmospheric Chemistry and Physics, 15(8), 4399-4981. https://doi.org/10.5194/acp-15-4399-2015

Schuur, E. A., McGuire, A. D., Schädel, C., Grosse, G., Harden, J. W., Hayes, D. J., et al. (2015). Climate change and the permafrost carbon feedback. Nature, 520(7546), 171-179. https://doi.org/10.1038/nature14338

Stewart, K. J., Grogan, P., Coxson, D. S., \& Siciliano, S. D. (2014). Topography as a key factor driving atmospheric nitrogen exchanges in arctic terrestrial ecosystems. Soil Biology and Biochemistry, 70, 96-112. https://doi.org/10.1016/j.soilbio.2013.12.005

Stieglitz, M., Shaman, J., McNamara, J., Engel, V., Shanley, J., \& Kling, G. W. (2003). An approach to understanding hydrologic connectivity on the hillslope and the implications for nutrient transport. Global Biogeochemical Cycles, 17(4), 1105. https://doi.org/10.1029/ 2003GB002041

Tang, G., Zheng, J., Xu, X., Yang, Z., Graham, D. E., Gu, B., et al. (2016). Biogeochemical modeling of $\mathrm{CO}_{2}$ and $\mathrm{CH}_{4}$ production in anoxic Arctic soil microcosms. Journal of Geophysical Research: Biogeosciences, 13, 5021-5041. https://doi.org/10.5194/bg-13-5021-2016

Thormann, M. N., Szumigalski, A. R., \& Bayley, S. E. (1999). Aboveground peat and carbon accumulation potentials along a bog-fen-marsh wetland gradient in southern boreal Alberta, Canada. Wetlands, 19(2), 305-317. https://doi.org/10.1007/BF03161761

Tian, H., Xu, X., Liu, M., Ren, W., Zhang, C., Chen, G., \& Lu, C. (2010). Spatial and temporal patterns of $\mathrm{CH}_{4}$ and $\mathrm{N}_{2} \mathrm{O}$ fluxes in terrestrial ecosystems of North America during 1979-2008: Application of a global biogeochemistry model. Journal of Geophysical Research: Biogeosciences, 7, 2673-2694. https://doi.org/10.5194/bg-7-2673-2010

Valentine, D. W., Holland, E. A., \& Schimel, D. S. (1994). Ecosystem and physiological controls over methane production in northern wetlands. Journal of Geophysical Research, 99(D1), 1563-1571. https://doi.org/10.1029/93JD00391

Wang, H. J., Shi, X. Z., Yu, D. S., Weindorf, D. C., Huang, B., Sun, W. X., et al. (2009). Factors determining soil nutrient distribution in a small-scaled watershed in the purple soil region of Sichuan Province, China. Soil and Tillage Research, 105(2), 300-306. https://doi.org/ 10.1016/j.still.2008.08.010

Wang, Q., Garrity, G. M., Tiedje, J. M., \& Cole, J. R. (2007). Naïve Bayesian classifier for rapid assignment of rRNA sequences into the new bacterial taxonomy. Applied and Environmental Microbiology, 73(16), 5261-5267. https://doi.org/10.1128/AEM.00062-07

Weishaar, J. L., Aiken, G. R., Bergamaschi, B. A., Fram, M. S., Fujii, R., \& Mopper, K. (2003). Evaluation of specific ultraviolet absorbance as an indicator of the chemical composition and reactivity of dissolved organic carbon. Environmental Science \& Technology, 37(20), 4702-4708. https://doi.org/10.1021/es030360x

Xu, X., \& Tian, H. (2012). Methane exchange between marshland and the atmosphere over China during 1949-2008. Global Biogeochemical Cycles, 26, GB2006. https://doi.org/10.1029/2010GB003946

Yang, Z., Wullschleger, S. D., Liang, L., Graham, D. E., \& Gu, B. (2016). Effects of warming on the degradation and production of lowmolecular-weight labile organic carbon in an Arctic tundra soil. Soil Biology and Biochemistry, 95, 202-211. https://doi.org/10.1016/j. soilbio.2015.12.022

Yano, Y., Shaver, G. R., Giblin, A. E., Rastetter, E. B., \& Nadelhoffer, K. J. (2010). Nitrogen dynamics in a small arctic watershed: Retention and downhill movement of 15N. Ecological Monographs, 80(2), 331-351. https://doi.org/10.1890/08-0773.1

Ye, R., Jin, Q., Bohannan, B., Keller, J. K., McAllister, S. A., \& Bridgham, S. D. (2012). pH controls over anaerobic carbon mineralization, the efficiency of methane production, and methanogenic pathways in peatlands across an ombrotrophic-minerotrophic gradient. Soil Biology and Biochemistry, 54, 36-47. https://doi.org/10.1016/j.soilbio.2012.05.015

Yoo, K., Amundson, R., Heimsath, A. M., \& Dietrich, W. E. (2006). Spatial patterns of soil organic carbon on hillslopes: Integrating geomorphic processes and the biological C cycle. Geoderma, 130(1-2), 47-65. https://doi.org/10.1016/j.geoderma.2005.01.008

Zalman, C., Keller, J. K., Tfaily, M., Kolton, M., Pfeifer-Meister, L., Wilson, R. M., et al. (2018). Small differences in ombrotrophy control regional-scale variation in methane cycling among Sphagnum-dominated peatlands. Biogeochemistry, 139(2), 155-177. https://doi.org/ 10.1007/s10533-018-0460-Z

Zheng, J., Philben, M., Zhang, L., Jubb, A., Bill, M., Wullschleger, S. D., et al. (2019). Surface and active layer water chemistry, Teller Road Mile Marker 27, Seward Peninsula, Alaska, 2016-2018. Next Generation Ecosystem Experiments Arctic Data Collection, Oak Ridge National Laboratory, U.S. Department of Energy, Oak Ridge, Tennessee, USA. Retrieved October 1, 2019, from https://doi.org/10.5440/ 1567181

Zheng, J., Thornton, P. E., Painter, S. L., Gu, B., Wullschleger, S. D., \& Graham, D. E. (2019). Modeling anaerobic soil organic carbon decomposition in Arctic polygon tundra: Insights into soil geochemical influences on carbon mineralization. Journal of Geophysical Research: Biogeosciences, 16, 663-680. https://doi.org/10.5194/bg-16-663-2019 